\title{
Towards a Global Framework to Measure and Assess Circular Economy*
}

\author{
Claudio Perissinotti Bisoni ${ }^{* *}$, Carlo Brondi ${ }^{* * *}$, \\ Claudio Rosso ${ }^{* * * *}$, Laura Cutaia ${ }^{* * * * *}$
}

\begin{abstract}
The growth in the relevance of the circular economy is confirmed today by the presence of numerous concurrent initiatives at a global level in terms of both policy level and labelling initiatives. Despite the presence of these initiatives, there is still no international agreement on systems to measure this effort. The ISO/TC 323 initiative aims precisely to develop responses to this challenge over the next three years. This article presents the main features of this initiative, in particular WG3 at a global level and the parallel UNI/CT 057 initiative.
\end{abstract}

Keywords: Circular Economy; Standardization; Circular Economy Indicators; ISO; Sustainability; Sustainability Metric; UNI CT 057; Industrial Symbiosis; Global Markets

\section{Standardization Framework}

UNI (Italian Standardization Body) has undertaken within the technical committee CT 057 "Circular economy" a path at national and international level to support organizations in defining circular economy indicators. A systematic framework dealing with the circularity problem is emerging as essential in view of the emerging global challenges. These national and global challenges both concern the connection between industrial economies and the ecosystem (climate warming, resource consumption, pollution) and the connection between traditional development models based on linear economy and economic models based on "recovery economies" (valorization of existing resource stocks, minimization of waste, optimized use of products, use of local resources, promotion of local wealth, etc.). In this context, UNI/CT 057 group operates in terms of connection with the territory of relevant stakeholders (public research bodies, development agencies, ministries, companies and sector associations) according to a bottom-up strategy in order to enhance existing practices and to implement truly effective approaches. Such initiative is part of a higher global initiative at global level.

\footnotetext{
* Invited Article

** Technical Officer at UNI (Italian Standardization Body) (claudio.perissinotti@uni.com)

*** Senior Researcher at STIIMA-CNR (National Research Council) (carlo.brondi@ stiima.cnr.it)

***** AICQ Nazionale (Italian Association Culture and Quality) (rosso@gruppocs.com)

******ENEA, Chairperson of UNI/CT 057 (laura.cutaia@enea.it)
}

Edited by: Niccolò Cusano University

ISSN: $1593-0319$

Perissinotti Bisoni, C., Brondi, C., Rosso, C., \& Cutaia, L. (2020). Towards a Global Framework to Measure and Assess Circular Economy. Symphonya. Emerging Issues in Management (symphonya.unicusano.it), (1), 88-100. 


\subsection{The ISO Technical Committee on Circular Economy}

The international circular economy point of reference in the standardization sector is ISO/TC 323 Circular Economy. Such new initiative has been created in September 2018 and it is composed by experts from 81 countries ( 72 participating members and 9 observing members). The Secretariat of such labelling initiative is AFNOR (Association Française de Normalisation), the French standard body. The committee includes several liaisons with other ISO Technical Committees and external organizations.

The aim of ISO/TC 323 is to develop definitions, frameworks, guidance, supporting tools, business models, key performances indicators and requirements for the implementation of circular economy of all involved organizations. ISO/TC 323 contributes, through its work items, to 16 United Nations Sustainable Development Goals.

Figure 1: ISO/TC 323 Circular Economy Worldwide Participation

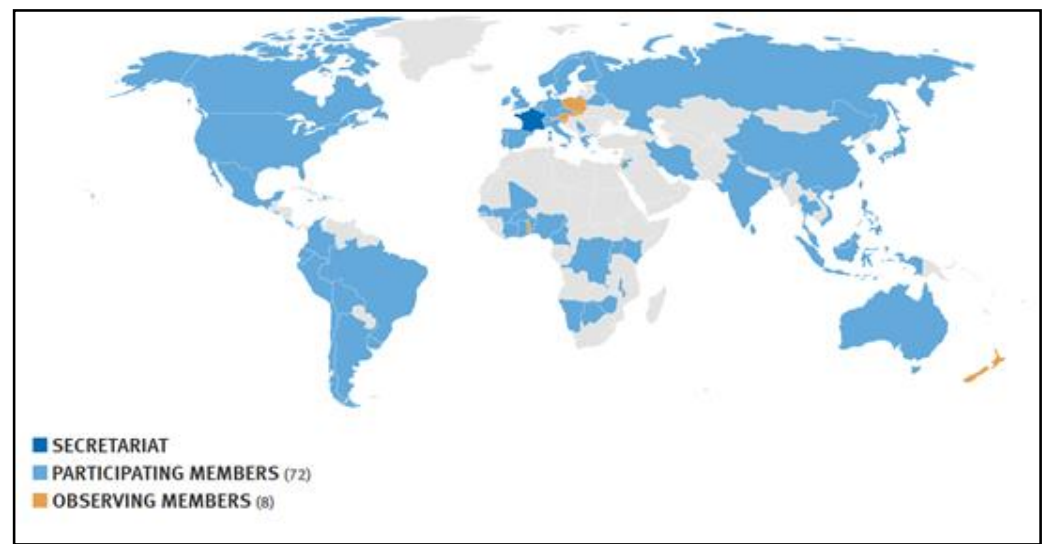

Source: ISO (2020, July).

ISO/TC 323 kick off meeting was held on May 2019 in Paris. From June to December 2019, ISO/TC 323 groups worked on 4 new work item proposals (3 international standards and 1 technical report). New work item proposals were voted and accepted by participating members on February and March 2020. Each proposals will include political, economic, technical, regulatory, legal and social aspects.

Figure 2: ISO/TC 323 Circular Economy Contribution to UN SDGs

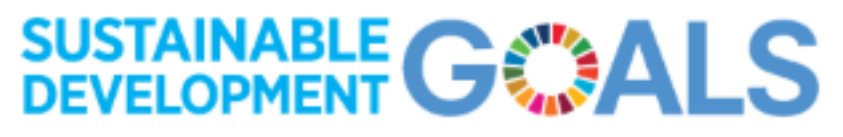

\section{\begin{tabular}{l|l|l|l|l|l|l|l|l|l|l|l|l|l|l|l|}
1 & 2 & 3 & 4 & 5 & 6 & 7 & 8 & 9 & 10 & 11 & 12 & 13 & 14 & 15 & 16 \\
\hline
\end{tabular}}

Source: ISO (2020, July) - ISO standard constitute the set up framework for ISO/TC 323 initiative.

The cornerstone for the setup of this initiative is given by the Sustainable Development Goals that have been gradually integrated into the standardization 
systems. The standards regarding sustainability during development identify a direct correspondence with the sustainability objectives in order to improve their contribution towards the effective sustainability of standardization activities. The assumption of all works is that an unlimited growth in a world of limited resources (linear economy) is not sustainable and it can produce negative social and environmental impacts. Economic principles should be inspired by the cycles observed in nature (e.g., water cycle, nitrogen cycle, carbon cycle) to be more efficient.

Table 1: ISO/TC 323 Working Groups, Work Item Proposals and Proposed Standards Development Track

\begin{tabular}{|l|l|l|}
\hline Working groups & \multicolumn{1}{|c|}{ Work item proposals } & \multicolumn{1}{|c|}{$\begin{array}{c}\text { Proposed standards } \\
\text { development track }\end{array}$} \\
\hline $\begin{array}{l}\text { WG 1 - Framework, } \\
\text { principles, terminology, } \\
\text { and management system } \\
\text { standard }\end{array}$ & $\begin{array}{l}\text { ISO/WD 59004 } \\
\text { Circular economy - Framework } \\
\text { and principles for implementation }\end{array}$ & $\begin{array}{l}36 \text { months } \\
\text { (planned publication: early 2023) }\end{array}$ \\
\hline $\begin{array}{l}\text { WG 2 - Guidance for } \\
\text { implementation and } \\
\text { sectoral applications }\end{array}$ & $\begin{array}{l}\text { ISO/WD 59010 } \\
\text { Circular economy - Guidelines on } \\
\text { business models and value chains }\end{array}$ & $\begin{array}{l}36 \text { months } \\
\text { (planned publication: early 2023) }\end{array}$ \\
\hline $\begin{array}{l}\text { WG 3 - Measuring } \\
\text { circularity }\end{array}$ & $\begin{array}{l}\text { ISO/WD 59020 } \\
\text { Circular economy - Measuring } \\
\text { circularity framework }\end{array}$ & $\begin{array}{l}36 \text { months } \\
\text { (planned publication: early 2023) }\end{array}$ \\
\hline $\begin{array}{l}\text { WG 4 - Specific issues of } \\
\text { circular economy }\end{array}$ & $\begin{array}{l}\text { ISO/CD TR 59031 } \\
\text { Circular economy - Performance- } \\
\text { based approach - Analysis of cases } \\
\text { studies }\end{array}$ & $\begin{array}{l}\text { 18 months } \\
\text { (planned publication: 2021/early } \\
\text { 2022) }\end{array}$ \\
\hline
\end{tabular}

Source: ISO (2020, July).

\subsection{Identification of Framework and Definition of Circular Economy}

ISO/WD 59004 specifies a framework, definitions and principles of circular economy, as well as a guidance for its implementation. This standard provides principles related to:

- Actions: they cover the value chain with the perspective of life cycle thinking including sourcing, circular design, industrial ecology/symbiosis, functional/service economy, reverse logistic, product life extension, resource management, and so on. Actions are considered from an environmental, social and economic perspective.

- Relationship and behavior: Change of collaborative mode and behavior supports shifting to a circular economy. This includes transparency, collaboration, partnership and any mean facilitating their adoption including virtualization and data management.

- Management of change: A framework for changing processes including system thinking, innovation, stewardship, value-based long-term economy will facilitate adoption by all. 


\subsection{New Business Models for Circular Economy}

ISO/WD 59010 provides organizations with guidelines on basic aspects that are needed to develop business models and value chains that contribute effectively to a circular economy. The circular business model of organizations should include a combination of activities along the value chain such as sourcing, circular design, industrial ecology/symbiosis, functional/service economy, reverse logistic, product life extension, (waste to) resource management. The use of Life Cycle thinking (LCT) will allow for better understanding of trade-offs and ensure circularity. This document will develop and provide guidelines for the implementation of circular business models and circular value chains by organizations including:

- Circular business model(s) can be distinguished according to a number of strategies, such as circular design, circular use, circular recovery, etc.

- A framework to assess the implementation of the chosen business model(s) by an organization will be proposed. It will address how organizations plan, analyze, evaluate and communicate circular business models or otherwise, how they integrate circularity into already existing business models.

\subsection{Measuring and Assessing Circular Economy}

ISO/WD 59020 specifies a generic framework for measuring and assessing circularity, taking into consideration the sustainability (environmental, social and economic) impacts of circular activities. This standard considers an integrated view or holistic thinking of circularity and sustainability, and it is intended to be used to maximize the positive impacts and to prevent and minimize the negative impacts on sustainable development.

\subsection{Implementation of Circular Economy in Organizations}

ISO/CD TR 59031 gives analysis of cases studies for the implementation of specific aspects of circular economy in organizations' activities, whatever their status can be. The proposed TR specifically focuses on performance-based approaches such as functional economy, service economy, product economy, product-service systems (PSS), Product as a Service (PaaS) and other meanings

\section{UNI/CT 057 Initiative}

A particular effort was performed within the ISO 59000 scheme at national level in order to address the topic on the measurement of circularity (WD 59010). Within WG3 works, UNI/CT 057 has started a parallel initiative for clustering and mapping existing indicators in order to support the global initiative and to further evidence possible lacks in measurements. As a starting point, general overview on the existing reference indicators has been provided within the Ad Hoc Group (AHG). Ad Hoc Group 03 was the basis for the birth of WG3 and consisted in a preliminary group of experts providing a drafting scheme for the incoming standard and a list of existing State-of-the-Art on the circularity measurement. 


\subsection{State-of-the-Art from ISO Ad Hoc Groups}

The annex A of Measuring circularity Explanatory Note allowed to collect a series of reference documents that were used as the basis for the work globally. These documents included:

- Methodological position paper;

- Tools and methodologies existing and already applied at different levels;

- Scientific literature on the measurement and assessment of the circular economy.

Figure 3: ISO/TC 323 AHG 3 Measuring Circularity Explanatory Note - Annex A - Indicators List

\begin{tabular}{|c|c|c|}
\hline 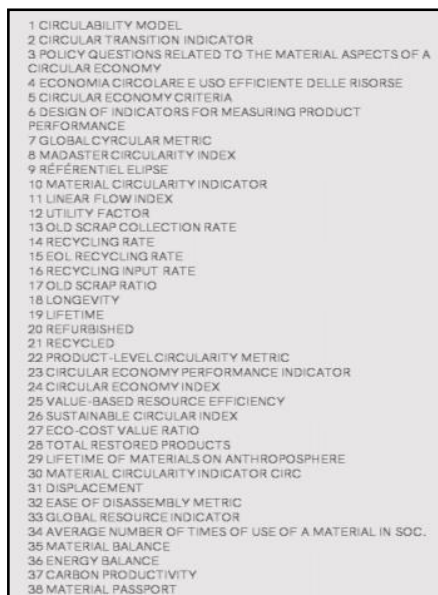 & 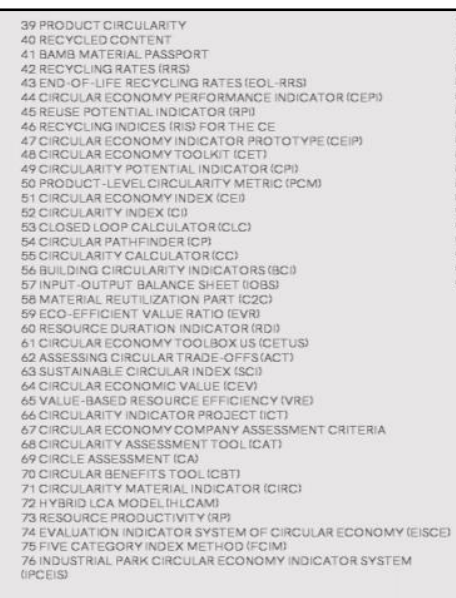 & 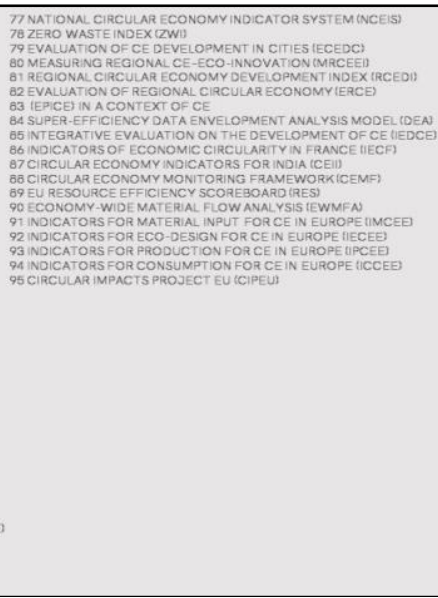 \\
\hline
\end{tabular}

The total of these works is 95 reference documents that constitute the starting point for the genesis of circularity indicators. This list will be further expanded and deepened in the coming years as well as the methodology itself.

The general problem concerning the definition of a proper set of indicators to measure circularity starting from the state-of-the-art through a transparent and unambiguous procedure mainly regards the diversity of sources. In fact, many references (which we can also call Indicator Systems) include different kinds of works. From one side, scientific works and proved methodologies provide welldetailed aspects at a quantitative level by both defining high-level indicators and subindicators according to a precise hierarchy.

These assessment systems seem complex, so it is appropriate to extrapolate individual sub-indicators that are reusable in a wider context. Other references also provide stand-alone indicators or quality systems that are difficult to apply or that are applicable to a very specific context (e.g., cities or nations). The underlying scientific problem therefore concerns the aggregation of indications from a very heterogeneous reference base.

The approach followed by UNI/CT 057, and reported at a higher level in the WG3 sub-group "Indicators" at ISO level, is a bottom-up approach. 


\subsection{Methodological Approach for Clustering}

The elaborated approach is proposed as a bottom-up approach in order to systematically analyze different sources according to three stages:

the first stage consists in the identification of the reference sources and the setup of a group of experts to examine the sources and take an initial uncritical examination;

- the second stage provides for a more detailed reading according to specific features. These features are selected by experts and are standard features that serve to qualify the salient features of a circularity indicator;

- the third stage includes a reanalysis and rereading of the sources through the extrapolation of the identified indicators and their clustering according to the identified features.

Figure 4: Bottom up Approach for Indicator Clustering

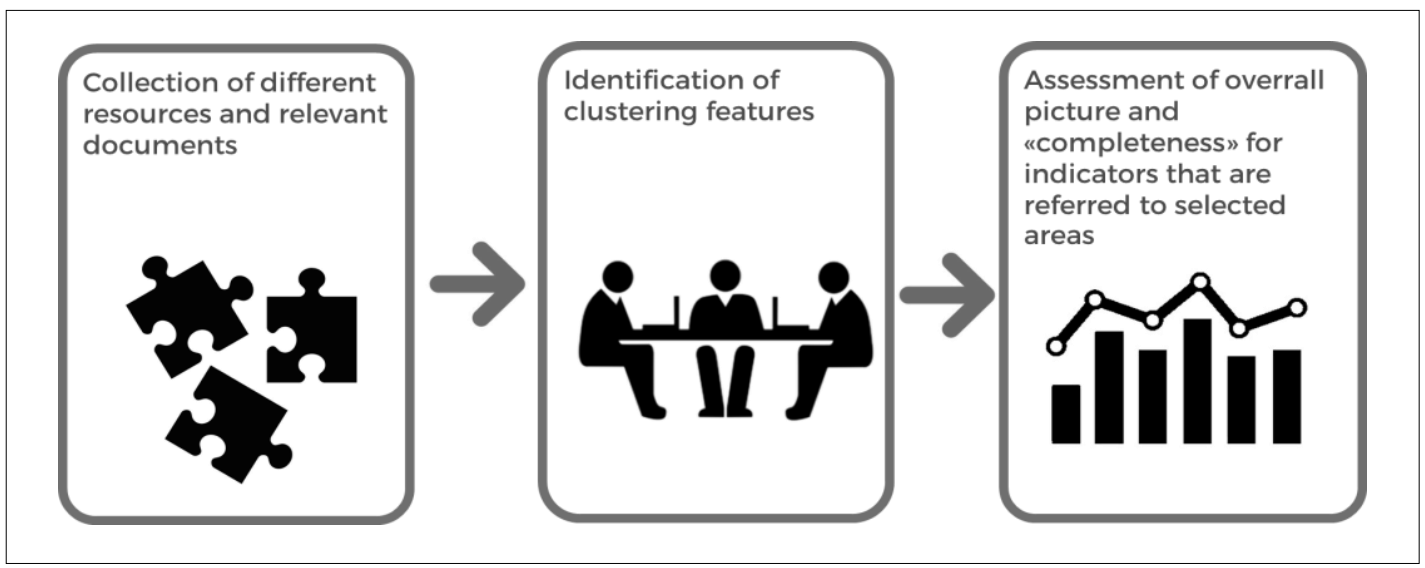

This approach aims primarily to identify areas in terms of measurement density that result more populated than other areas.

By this way, it is possible to highlight any gaps in the standardization aspects (e.g., some areas that have few indicators or areas for which they have not yet been identified). Secondly, by integrating some key features such as the calculability and scalability of an indicator, it becomes possible to create criteria to eliminate references that are not meaningful.

Finally, the last relevant aspect of the bottom-up approach is the identification of similar indicators and their integration. In fact, many indicators can be used in a similar way within different contexts (e.g., indicators on recyclability). The detailed definition of a series of features allows identifying indicators in the same area and with the same characteristics before being able to aggregate them. 
Figure 5: Correlation Matrix

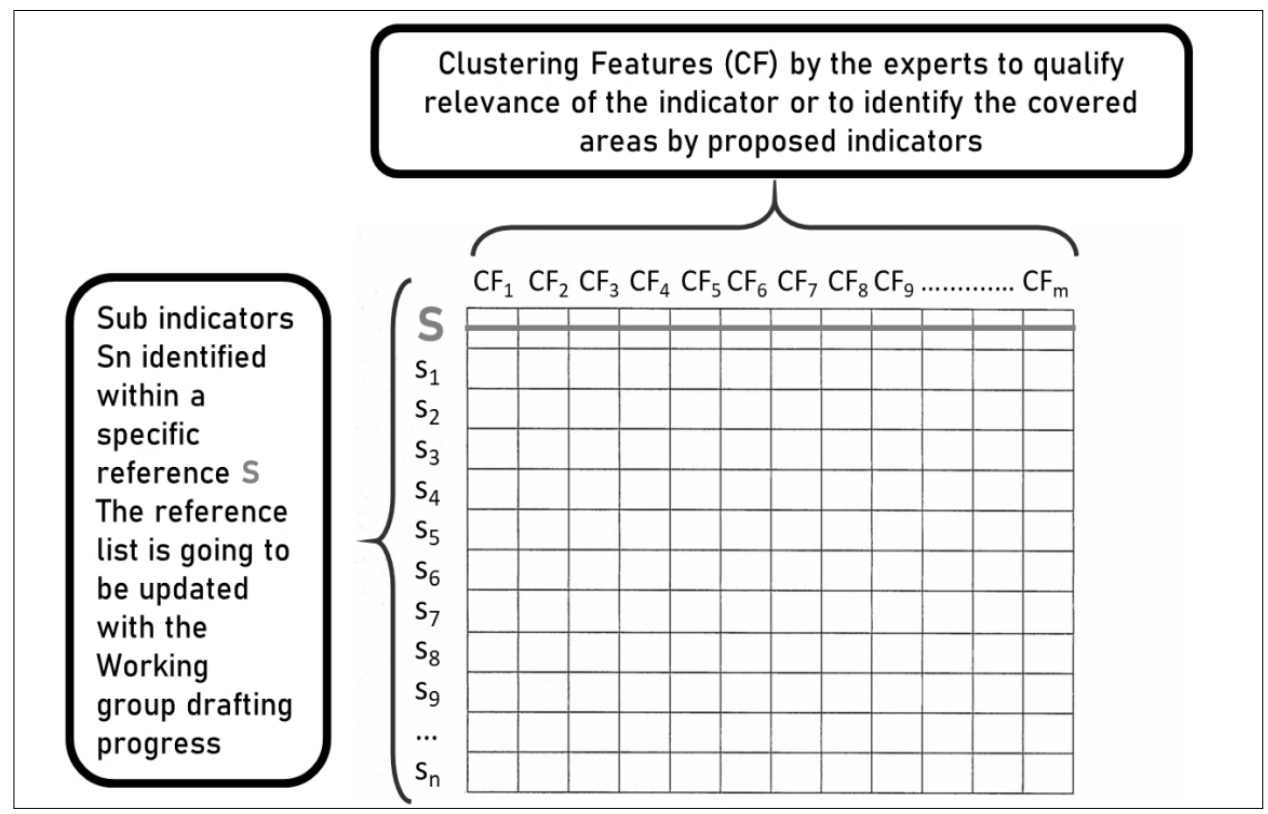

Clustering areas or clustering features can concern many qualifying aspects for the circular economy. The non-exhaustive list of these categories concerns:

- The circularity aspects: this macro area concerns the measurement of flows and activities connected to the "physical circularity" paradigm: an example is the monitoring of the closure of energy and material cycles (e.g., energy reuse, use of recycled materials, consumption of water, etc.).

- The effect of circularity: this type of indicators monitors the effect on different types of areas both in terms of overall performance and other complementary effects (e.g., indicators on social impact, indicators on environmental impact, indicators of an economic type, indicators that refer to innovation).

- The context of circularity: this macro area concerns the area of action of the indicator system (e.g., type of policy for which it can be used, phase of the life cycle that is monitored, industrial sectors of application).

- The indicator type: this macro area qualifies the characteristics of the indicator with a view to its origin and reuse (e.g., indicator, quantitative, qualitative, semiquantitative, calculability, type of source from which it comes).

- Ad hoc focus on circularity: some features are measured that are strategic in terms of circularity economy (e.g., indications on industrial symbiosis, indications on business models, temporal aspects, compliance with political initiatives, etc.). 
Figure 6: Example of Clustering Features

\begin{tabular}{|c|c|c|}
\hline $\begin{array}{l}\text { INDICATOR TYPE } \\
\text { Qualitative } \\
\text { Semiquantitative } \\
\text { Qualitative } \\
\text { Calculable }\end{array}$ & $\begin{array}{ll}\text { CIRCULARITY ASPECTS } \\
\text { Energy Consump/waste } \\
\text { Mat. consumption/waste } \\
\text { Water consumpt/waste } \\
\text { Reused part... }\end{array}$ & $\begin{array}{l}\text { ENVIRONMENTAL FEATURES } \\
\text { Water pollution } \\
\text { Air pollutions } \\
\text { Harmful substances } \\
\text { Global impact (LCA) }\end{array}$ \\
\hline $\begin{array}{l}\text { COVERED AREAS } \\
\text { Macro } \\
\text { Meso } \\
\text { Micro } \\
\text { Nano }\end{array}$ & $\begin{array}{l}\text { PROPOSER TYPE } \\
\text { Geo } \\
\text { Private entity } \\
\text { Public Entity } \\
\text { Scientific community... }\end{array}$ & $\begin{array}{l}\text { SOCIAL FEATURES } \\
\text { Community benefits } \\
\text { Worker health } \\
\text { Education } \\
. . .\end{array}$ \\
\hline $\begin{array}{l}\text { INNOVATION } \\
\text { Process } \\
\text { Product } \\
\text { Organization } \\
\text { Waste Man }\end{array}$ & $\begin{array}{l}\text { Policy aspects } \\
\text { Nationa level } \\
\text { City level } \\
\text { Network level } \\
\text { Company level... }\end{array}$ & $\begin{array}{l}\text { ECODESIGN ASPECTS } \\
\text { Duration } \\
\text { Recyclability } \\
\text { Compostability } \\
\text {..... }\end{array}$ \\
\hline $\begin{array}{l}\text { LIFE CYCLE } \\
\text { Raw material extraction } \\
\text { Production } \\
\text { Use } \\
\text { EOL }\end{array}$ & $\begin{array}{l}\text { OTHER FEATURES } \\
\text { Symbiosis aspects } \\
\text { Temporal aspects } \\
. . .\end{array}$ & $\begin{array}{l}\text { ECONOMIC FEATURES } \\
\text { Investment } \\
\text { Revenue } \\
\text { Contribution to GDP } \\
. . .\end{array}$ \\
\hline
\end{tabular}

\subsection{Discussion of Current Implementation}

Some important issues that have been clarified during the preparation of the work by the experts of ISO/TC 323 concern the role of the indicators, the overlap with other standards and the subdivision into levels for the standard in question.

There is a possible partial overlap with other existing regulations (e.g., ISO 14000, ISO 26000, etc.). The overlap concerns in particular the assessment phase that for the series of rules is concentrated only on the aspects of circularity. In this sense, it is important to distinguish three areas in which the final indicators can compete.

1. Area 1 - Measurement of circularity - A first area concerns measurement activity; the indicators therefore measure aspects that are attributable to circularity.

2. Area 2 - Assessment of circularity - This area concerns the assessment of circularity. This phase concerns an assessment of the impact obtained with respect to a performance target, and indicators that are identified; therefore; it concerns the effectiveness of a set of previously measured aspects to an overall effect. Such indicators can also take the form of semi-quantitative indexes. In this perspective, a first draft of the standard could follow the same structure of ISO 14000 that included this data aggregation framework into summary indicators able to spot an overall effect.

3. Area 3-Complementary assessment - The third area concerns the link of these indicators to indicators that are already present in other existing or developing ISO standards. As illustrative example, the environmental effects of a process solution fall within the competence of ISO TC 207. Equally, new regulations in this area in their revision phase include adjustments to the Circular Economy Issue. Another example of these indicators is the revision of the ISO 14006 ecodesign criteria for products, the dual logo initiative for the standardization of the material declaration by ISO TC 207 and IEC TC 111 and the ISO Technical commission on the sharing economy. All these initiatives are going to integrate 
further indicators on circularity aspects that could be linked with emerging ISO/TC 323 scheme.

Figure 7: Role of Indicators within the Emerging Framework

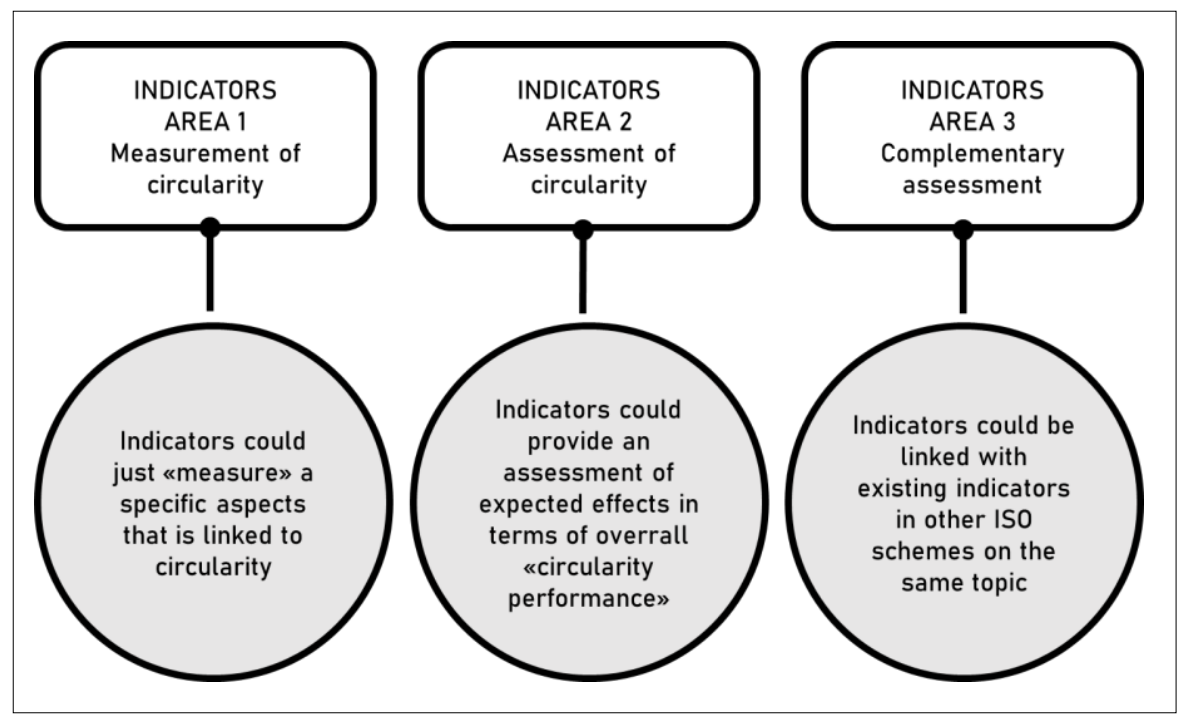

Another key aspect concerns the subdivision in the spillover area of the various indicators. In fact, the framework of ISO/WD 59020 is built in order to cover different scale of circularity actions. In such sense, currently four areas have been identified in order to define a specific set of indicators:

- Macro level covers large geographical scale such as countries and large European regions (e.g., Europe, Africa, etc.).

- Meso level covers both local geographical areas such as cities, districts or company networks and supply chains in which circular initiatives such as industrial symbiosis take place.

- Micro level covers company and facility level in which contextual actions take place.

- Nano level covers product level in terms of specific features and qualities involving circular aspects.

The macro-meso-micro-nano subdivision reports only generically the names of the areas that are going to be changed during the standard development process.

Furthermore, the development of the standard could highlight the need to exclude some levels of analysis in order to focus on those on which it actually makes more sense to trace the circularity. In terms of issue, many indicators have been developed for different purposes and tend to cover very different levels of circularity. These aspects tend to emerge or manifest only from a certain level onwards. For example, an indicator such as the average income of workers in the recovery sector is a parameter of economic effect that typically concerns a macro level, while the percentage of recycled material within a product is a measurement area that concerns the nano-level. 
Figure 8: Scale for Application of Circular Economy (Ce) Indicators

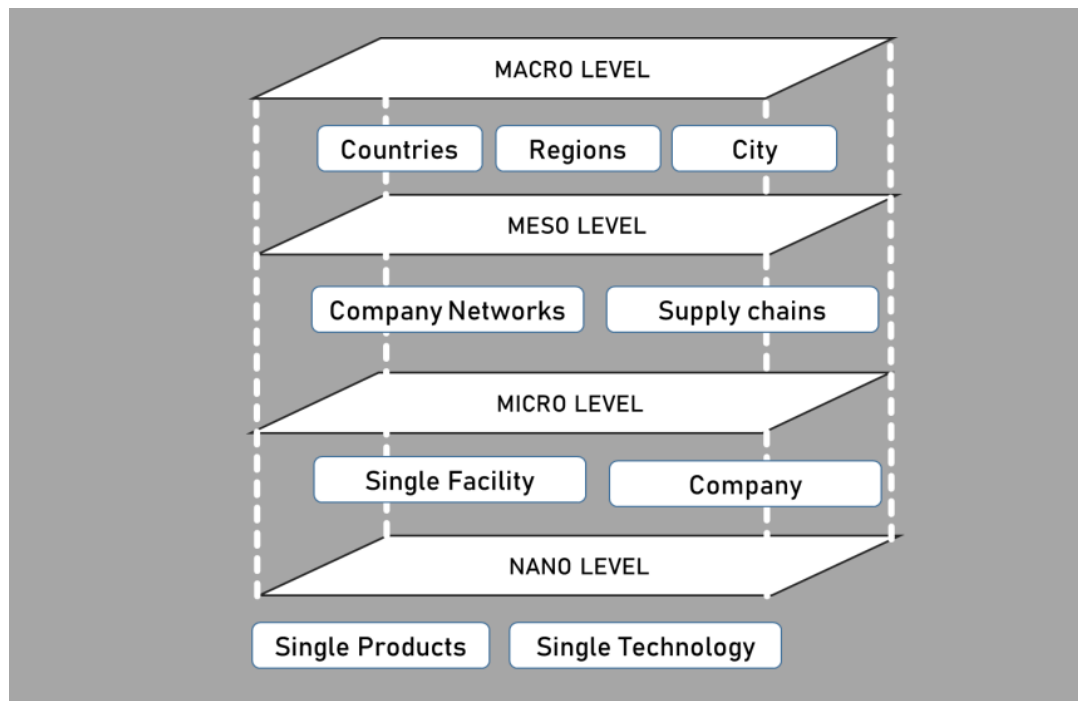

\section{General Outcomes from the UNI/CT 057 Initiative}

A first extrapolation of the data on the 95 references of the Annex A revealed some trend on the distribution of the indicators in literature. In general, some areas such as the company or product level (micro and nano level) are well covered, while others appear to be more intangible and less subject to measurement activity. Such areas concern for example the duration of the products, the migration of a material from one product chain to another, the exchange of by-products between companies. Such areas may be subject to further studies or further compensation within ISO work.

In terms of methodological approach, the correlation approach is going to be adopted at global level in the indicator sub-team within ISO WG3 group. The success of such approach seems partly to demonstrate the need for a bottom-up tracking of existing efforts; similarly, such approach seems functional to govern the massive production of different initiatives.

Figure 9: Extrapolation of Indicators Through the Correlation Approach

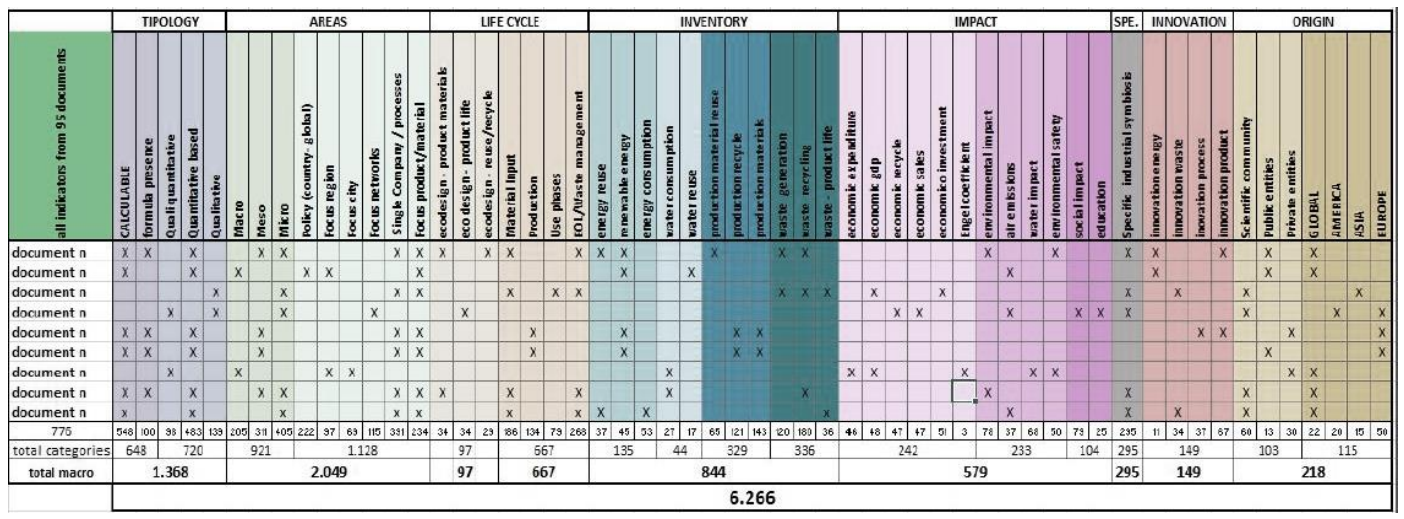


In terms of clustering areas for the level, some indicators can fall in different levels by providing a multilevel applicability (e.g., recycling rate for a certain material), while other indicators are level-specific (e.g., citizen average income due to recovery sector in the macro level). Such aspects should be not neglected since the circularity implies both a local performance assessment as well as a collaborative approach that should produce results at the upper level. For example, a good indicator system for a company provides also effects at meso level in terms of company network. Multilevel application of a single indicator can be then a valuable feature to be considered.

As general outcomes, scalability and measurability of proposed indicators appear as key transversal features to be accounted in the ISO working progress.

Scalability of specific indicators guarantees also the scalability of the tracking and supports a homogeneous framework for the assessment and policy system.

Instead, the effective calculability of single indicators both contributes to switch the tracking system from qualitative to quantitative framework and to support existing initiatives with proved results and issue on their applicability.

An illustrative example is the link with the Eurostat system at European level, i.e., a link with an already existing tracking system that also provides indications in terms of policy.

Figure 10: Source Type for Annex A Reference List

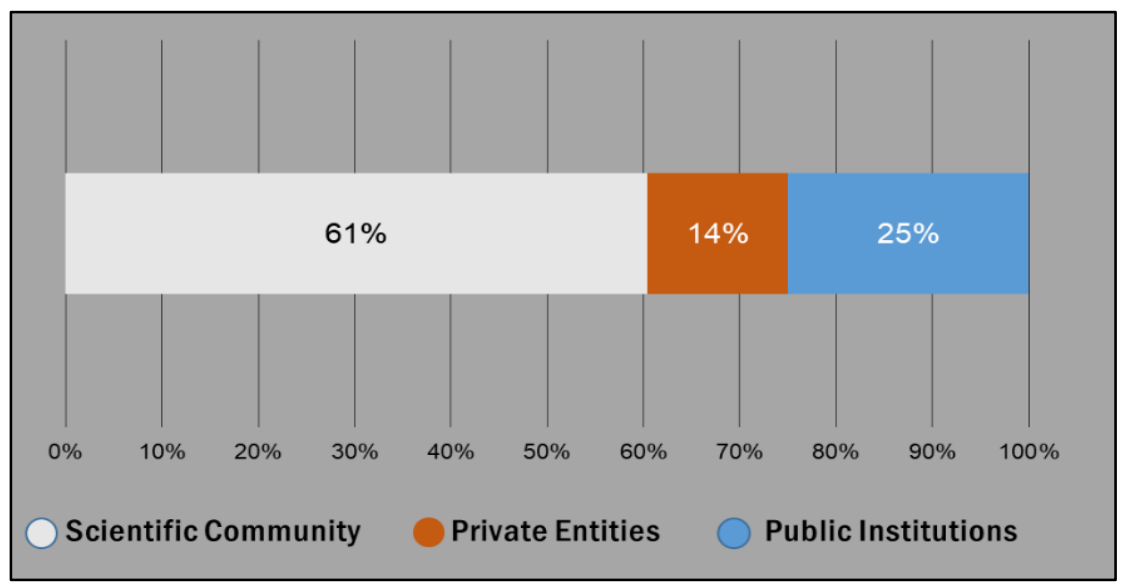

Although further developments are expected over the next few years, the UNI/CT 057 initiative has provided a basis for the comparison between different countries and jobs. The heterogeneity of the approaches also reflects a different representation of the same problem, which is based on the role of the proposer. $25 \%$ of the indicators proposed come from private entities concern the micro and nano area, while $61 \%$ of the indicators proposed by the scientific community have a broader approach in theoretical terms than application (macro and meso). A successful standard should consider greater integrability between these aspects to ensure a common sharing of intents not only political but also operational. 


\section{Bibliography}

Adibi, N., Lafhaj, Z., Yehya, M., \& Payet, J. (2017). Global Resource Indicator for Life Cycle Impact Assessment: Applied in Wind Turbine Case Study. Journal of Cleaner Production, 165, 1517-1528. http://dx.doi.org/10.1016/j.jclepro.2017.07.226

Azevedo, S., Godina, R., \& Matias, J. (2017). Proposal of a Sustainable Circular Index for Manufacturing Companies. Resources, 6(4), 63.

http://dx.doi.org/10.3390/resources6040063

Brondoni, S. M. (2019). Shareowners, Stakeholders \& the Global Oversize Economy. The CocaCola Company Case. Symphonya. Emerging Issues in Management (symphonya.unicusano.it), (1), 16-27. http://dx.doi.org/10.4468/2019.1.02brondoni

Brondoni, S. M., \& Bosetti, L. (2018). Ouverture de 'Integrated CSR Management'. Symphonya. Emerging Issues in Management (symphonya.unimib.it), (1), 1-17.

http://dx.doi.org/10.4468/2018.1.01ouverture

Civera, C., \& Freeman, R. E. (2019). Stakeholder Relationships and Responsibilities: A New Perspective. Symphonya. Emerging Issues in Management (symphonya.unicusano.it), (1), 40-58. http://dx.doi.org/10.4468/2019.1.04civera.freeman

Di Maio, F., \& Rem, P. C. (2015). A Robust Indicator for Promoting Circular Economy through Recycling. Journal of Environmental Protection, 6(10), 95-104.

http://dx.doi.org/10.4236/jep.2015.610096

Ellen MacArthur Foundation (2015). Circular Indicators: An Approach to Measuring Circularity. Methodology.

Franklin-Johnson, E., \& Figge, F. (2016). Canning L. Resource Duration as a Managerial Indicator for Circular Economy Performance, Journal of Cleaner Production, 133, 589-98.

http://dx.doi.org/10.1016/j.jclepro.2016.05.023

Freeman, R. E., \& Dmytriyev, S. (2017). Corporate Social Responsibility and Stakeholder Theory: Learning From Each Other, Symphonya. Emerging Issues in Management (symphonya.unimib.it), (2), 7-15.

http://dx.doi.org/10.4468/2017.1.02freeman.dmytriyev

Graedel, T. E., Allwood, J., Birat, J-P., Buchert, M., Hagelüken, C., Reck, B. K., Sibley, S. F., \& Sonnemann, G. (2011). What Do We Know About Metal Recycling Rates? Journal of Industrial Ecology, 15(3), 355-366.

http://dx.doi.org/10.1111/j.1530-9290.2011.00342.x

Huysman, S., De Schaepmeester, J., Ragaert, K., Dewulf, J., \& De Meester, S. (2017). Performance Indicators for a Circular Economy: A Case Study on Post-Industrial Plastic Waste, Resource Conservation Recycling, 120, 46-54.

http://dx.doi.org/10.1016/j.resconrec.2017.01.013

Lambin, E. (2017). Implementing the Transition to Sustainable Development, Symphonya. Emerging Issues in Management (symphonya.unimib.it), (1), 25-30.

http://dx.doi.org/10.4468/2003.1.03lambin

Linder, M., Sarasini, S., \& van Loon, P. (2017). A Metric for Quantifying Product-Level Circularity. Journal of Industrial Ecology, 21(3), 545-558.

http://dx.doi.org/10.1111/jiec.12552

Matsuno, Y., Daigo, I., \& Adachi, Y. (2007). Application of Markov Chain Model to Calculate the Average Number of Times of Use of a Material in Society. An Allocation Methodology for OpenLoop Recycling. Part 2: Case Study for Steel. The International Journal of Life Cycle Assessment, 12, 34-39.

http://dx.doi.org/10.1065/lca2006.05.246.2 
Pauliuk, S. (2018). Critical Appraisal of the Circular Economy Standard Bs 8001:2017 and a Dashboard of Quantitative System Indicators for Its Implementation in Organizations. Resources, Conservation and Recycling, 129, 81-92.

http://dx.doi.org/10.1016/j.resconrec.2017.10.019

Salvioni, D. M., \& Gennari, F. (2017). CSR, Sustainable Value Creation and Shareholder Relations, Symphonya. Emerging Issues in Management (symphonya.unimib.it), (1), 36-49.

http://dx.doi.org/10.4468/2017.1.04salvioni.gennari

Scheepens, A. E., Vogtländer, J. G., \& Brezet, J. C. (2016). Two Life Cycle Assessment (LCA) Based Methods to Analyse and Design Complex (Regional) Circular Economy Systems. Case: Making Water Tourism More Sustainable, Journal of Cleaner Production, 114, 257-268.

http://dx.doi.org/10.1016/j.jclepro.2015.05.075

Vanegas, P., Peeters, J. R., Cattrysse, D., Tecchio, P., Ardente, F., Mathieux, F., Dewulf, W., \& Duflou, J. R. (2017). Ease of Disassembly of Products to Support Circular Economy Strategies. Resources, Conservation and Recycling, 135, 323-334.

http://dx.doi.org/10.1016/J.RESCONREC.2017.06.022

Zink, T., Geyer, R., Startz, R. A. (2016). Market-Based Framework for Quantifying Displaced Production from Recycling or Reuse. Journal of Industrial Ecology, 20(4), 719-29.

http://dx.doi.org/10.1111/jiec.12317

\section{Notes}

The working group 4 - UNI/CT 057 thanks both Dr. Silvia Sbaffoni from ENEA and Dr. Giacomo Bertola for their indispensable contribution in mapping and defining the approach. This valuable effort was also indispensable for the drafting of this publication. 